\title{
空気圧シリコン外殼型発泡ゴムアクチュエータの開発*
}

\author{
早川恭 弘*1, 森下 賢 祐*2 \\ 相 地 美 奈*2, 津 田 竜 二*2
}

\section{Development of a Pneumatic Silicon Outer Fence Mold Actuator}

\author{
Yasuhiro HAYAKAWA*3, Kensuke MORISHITA, \\ Mina AICHI and Ryuuji THUDA \\ ${ }^{* 3}$ Nara National College of Technology, \\ 22 Yata-cho, Yamato-Koriyama, Nara, 639-1080 Japan
}

\begin{abstract}
In order to develop a human friendly support machine for elderly people, improvement of the interface between human and mechanical system has been becoming very important. Especially, soft mechanical interfaces are strongly required in motion assist machines for handicapped people or elderly people. Therefore, an actuator that has both active elements and passive elements attracts attention to design the soft mechanical interface. To realize these elements, we propose a new type of pneumatic soft actuator that a sponge rubber is covered with silicon rubber (Silicon Outer Fence Mold Actuator). In this paper, the structure of the actuator is explained. Furthermore, it is clarified that the characteristics of the actuator are influenced by the number of sponge layer and sponge material. Moreover, we clear position control performance of the actuator. That is to say, the effectiveness of the proposed actuator is cleared through some experimental results.
\end{abstract}

Key Words : Pneumatic Actuator, Silicon Rubber, Sponge Rubber, Soft Mechanism, Position Control

\section{1. 粕敦}

近年，日本では少子高齢化社会となり高齢者が高 齢者を介護する老老介護が増加している. そこで, 従 来の人的介護では高齢介護者の負担増加と人手不足が ますます深刻化することが考えられ，高齢者の介護を サポートするパワーアシスト装具或いは高齢被介護者 の自立を目的とした自立支援機器の開発が望まれてい る. これらの介護機器は人間との接触を伴うことから， 使用する人間に対し安全性が要求される. 安全性を確 保するための方法としては，ハードである機械的側面 (物理的) とソフトである知能的（情報的），心理的 （情緒的）側面に分類される. しかしながら，トラブ 儿発生時における被害を最小限に抑えるためには, 機 械的側面であるハードによる保障が重要であると思わ れる. すなわち, 機器のコントロールプログラムが暴 走し，操作に支障をきたしたり，誤動作を生じた場合 においても，ハード面において安全性が確保されてい れば, 最小限の被害に抑えることができる.

* 原稿受付 2003 年 4 月 1 日.

*1 正員, 奈良工業高等専門学校 $(\boldsymbol{E}$ 639-1080 大和郡山市矢田 町 22).

*2 奈良工業高等専門学校機械制御工学専攻.

E-mail : hayakawa@ctrl.nara-k.ac.jp
そこで, ハード面における安全性を確保するた めのアクチュエータとして, 空気圧を用いた要素の開 発が行われている. 例えば, 山本らは蛇腹形状の空気 圧アクチュエータをパワーアシスト装具に応用してい る(1). また, ウエアラブルシステムとして, 塚越らは Wound Tube Actratorを提案している®. さらに, 満田ら は粒子内蔵型機械拘束要素を用いて粘性を付加してい るの.これらの要素は, 小型・軽量化が容易であり, 使用者の動きに合わせて柔軟に駆動することができる.

しかしながら，小型・軽量化を図るためにゴム系 の空気圧アクチュエータを福祉介護機器に応用する場 合, 破裂などよる危険性が問題となると考えられる. すなわち，破裂により急激な形状変形が生じることに より，使用者に対し精神的肉体的負担を与えることと なることから，形状変形を抑制する構造が必要になる.

そこで, ゴム系空気圧アクチュエータの問題点を 解決するための一つの方法として，発泡ゴムにシリコ ンをコーティングしたシリコン外殼型発泡ゴムアクチ ユエーダのを提案する. 本論文では，第 2 章におい て, シリコン外殻型発泡ゴムアクチュエータの構造を 説明する. また, 第 3 章においては，発泡ゴム積層数 の違いによる基礎特性を明らかにする.ささらに，第 4 章でアクチュエータの位置制御性能を示す. 


\section{2. シリコン外殼型発泡ゴムアクチュエータ(1)(2)}

シリコン外殼型発泡ゴムアクチュエータ(Silion Outer FenœMold Actuator: : 以後 SOFMA)は、図 1 に示すよう に発泡ゴムをシリコンゴムでコーティングすることに より、空気を発泡ゴム多孔部に充填寸ることが可能な 構造である. 発泡ゴム多孔部体積は発泡ゴムの密度に 関係していることから, 密度が大きくなるほど多孔部 が減少し発泡ゴムの固有岡性が増大寸る. 寸なわち, 無加圧時におけるアクチュエータの弾力性は, 発泡ゴ ムの密度に左右される.ささらに, 発泡ゴム内に空気を 充填することによりアクチュエータの岡性を調整でき る. また, アクチュエータ破裂時における急激な形状 変形に対する衝撃力をアクチュエータ内部の発泡ゴム の弾性力により吸収することができると考えられる. このことから, SOFMAを介護機器などのサポータ部 に応用寸る場合, 安全性の観点から有効であると考え られる.
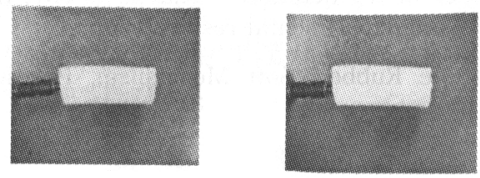

(b-1) Initial State

(b-2)Pressurized State

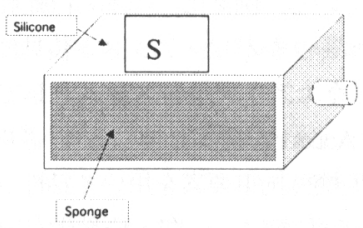

(a)Single layer Structure

Fig.1 Schematic View of Pneumatic Foaming Rubber Actuator

SOFMA は, アクチュエータ内部における発泡ゴム の積層数により, 以下のように分類される. すなわち, 一層型（図 1) と二層型(図 2)である.ここで, (b-1)は 無加圧時, (b-2)は加圧時の状態を示寸. 図 1 及び図 2 から明らかなように，一層型は加圧時における形状変 形が殆どないことが分かる.これは，シリコンが発泡 ゴムの外側に僅かに浸透していることから，シリコン の変形が発泡ゴムにより拘束されることによるもので ある. それに対し，発泡ゴムが二層型の場合，空気は

発泡ゴムの多孔部及び積層間にも充填されることによ り, 膨張変形する.

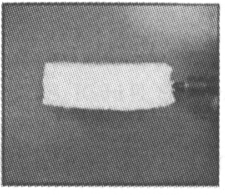

(b-1) Initial State

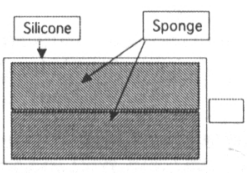

(a)Two Layers Structure

Fig.2 Schematic View of Pneumatic

Foaming Rubber Actuator

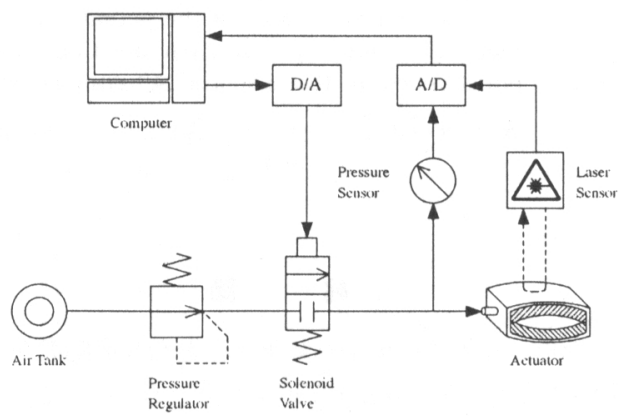

Fig.3 Experimental Setup

\section{3. 基礎特性}

\section{1 実験装置}

SOFMA の基礎特性を明らかにするため, 図 3 に示 す装置を用いる，すなわち，アクチュエータ内の圧力 は, 半導体圧力変換器により測定し, 変位量はレーザ 一変位計を使用寸る．また，発泡ゴムチャンバ内压力 調整には，電空流量比例弁を用いている.

本研究で使用する一層型及び二層型アクチュエー タの形状寸法は, $(79 \times 44 \times 25 \mathrm{~mm})$ である. また, アク チュエータ内発泡ゴムの材質は ECZ(密度 : 16士 $15 \mathrm{~kg}^{3}$ )或いは EMM(密度 : $52 \pm 3 \mathrm{~kg} \mathrm{~m}^{3}$ )を使用する.

\section{2 㓮性特性}

一層型或いは二層型構造を有する SOFMA の発泡ゴ 么部に圧力を充填する場合における剛性特性について 
明らかにする，そのため，アクチュエータ内に一定の 圧力を印加・密閉し外力をアクチュエータ表面に作用 させたときのアクチュエータ変位量を測定する.ここ で，発泡ゴム材質は， ECZを使用している.

発泡ゴムが一層型および二層型構造を有するアク チュエータに関する実験結果を図 4 に示す. 実験結果 より, 一層型構造の場合, 单層構造による形状変化の 抑制からアクチュエータの内圧が高いほど岡性が増大 することがわかる. それに対し，二層型構造の場合 (図 4(b))，内圧増大により形状が膨張するため内压 を増加させても剛性変化は見られない．

以上の結果より，一層型は剛性型であり，腰痛べ ルトやサポータ等の福祉要素に応用できると考えられ る. それに対し，二層型は膨張型となり，床ずれ防止 用マット等への応用が考えられる.

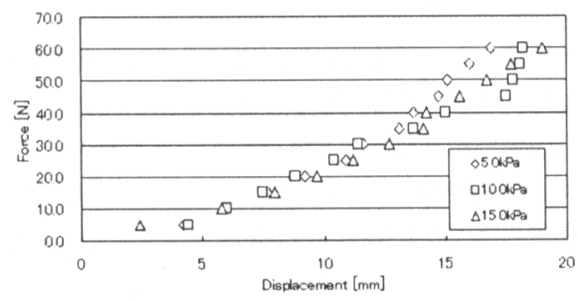

(b) Two Layers Type

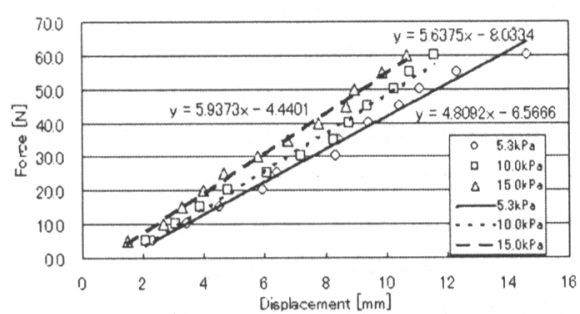

(a) One Layer Type

(x: Pressure, y: Force)

Fig.4 Experimental Results on Stiffness of Actuator

\section{3 ヒステリシス}

発泡ゴムの外側をシリコンゴムでコーティングさ れている二層型 SOFMA のアクチュエータ内圧と変位 量に関するヒステリシスを明らかにする．発泡ゴムの 材質は ECZ および EMM を用い，内圧を $1[\mathrm{kPa}]$ 間隔で $0[\mathrm{kPa}]$ から $12[\mathrm{kPa}]$, そして, $0[\mathrm{kPa}]$ と変化させた時の変 位量を測定する. 実験結果を図 5 に示す。ここで, 図 中(C), (D)は加圧時及び咸圧時の特性を示す.
実験結果より，ヒステリシスの最大值は，ECZ が $2.66 \mathrm{~mm}, \mathrm{EMM}$ が $1.22 \mathrm{~mm}$, 加圧前と減圧後の無加圧 状態におけるヒステリシスは，ECZが 2.66 mm，EMM の時が $032 \mathrm{~mm}$ となっている. すなわち, ECZの場合 は，無加圧状態でのヒステリシスが最大となり， EMM のヒステリシスは逆に小さい結果となった. こ れは, 密度の大きい EMM は変形前の形状に戻ろうと するバネ力が強いためであると考えられる.

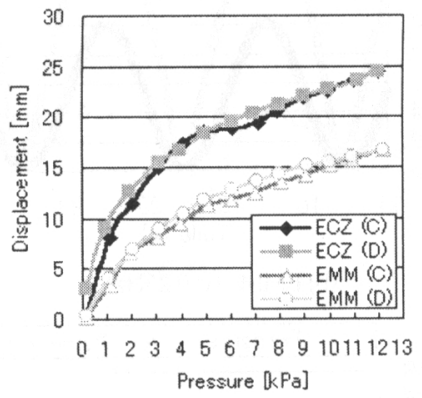

Fig. 5 Experimental Results on Hysteresis

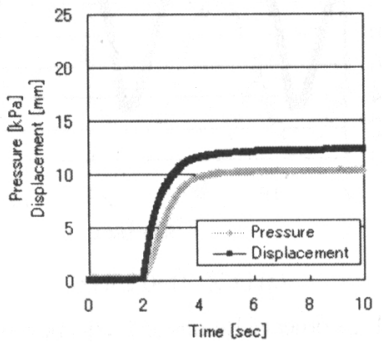

(b) Sponge Material: EMM

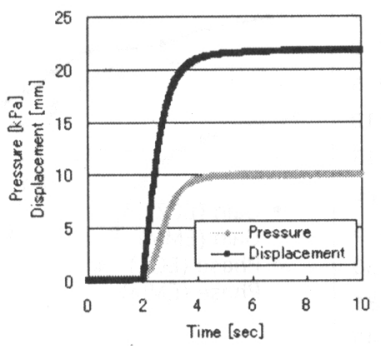

(a) Sponge Material: ECZ

Fig.6 Experimental Results on Step Response

\section{4 加圧時挙動}

二層型 SOFMA 内圧力を圧力レギュレータにより $10 \mathrm{kPa}$ まで加圧した場合における発泡ゴムの材質の違 いによる応答の変化を図 6 に示寸.ここで, SOFMA の形状寸法は 3.1 節で示したサイズと同じである. 図 6(a)は，発泡ゴム ECZ を用いた場合，図 6(b)は EMM を 
使用した時の内圧及び変位量である. 実験結果より, 密度の低い ECZ の変位量は約 $21.7 \mathrm{~mm}$, 密度の高い $\mathrm{EMM}$ は約 $12.1 \mathrm{~mm}$ 変位している. 寸なわち, 発泡ゴ ムの密度が小さくなるほど, バネ力が小さくなり, 変 位量が増大寸ることがわかる。

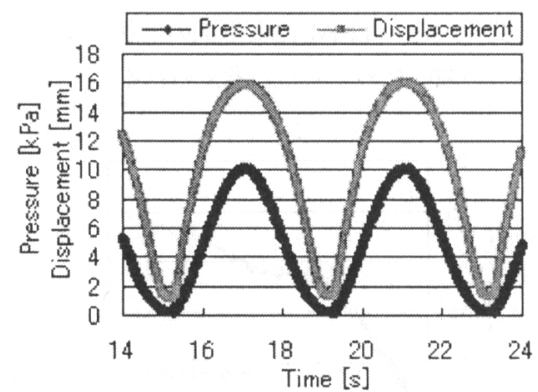

(b) $\mathrm{EMM} \quad(\mathrm{f}=0.25 \mathrm{~Hz})$

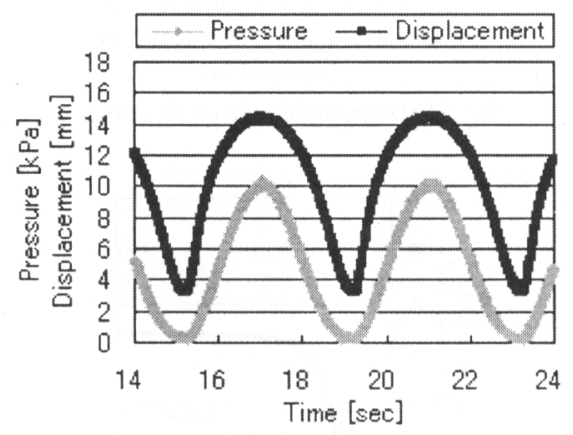

(a) ECZ $(\mathrm{f}=0.25 \mathrm{~Hz})$

Fig.7 Experimental Results on Frequency Response

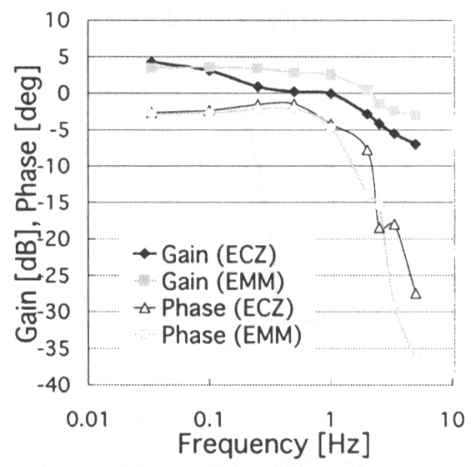

Fig. 8 Bode Diagram of $[x / p]$

\section{5 周波数応答}

SOFMA の周波数特性を明らかにするために, 発泡 ゴムチャンバ内圧力を正弦波状に変化させた時の変位 量を測定する. 実験では, 内圧変化に対し膨張する二 層型構造のアクチュエータを使用する. また, 発泡ゴ
ムは密度の異なる $\mathrm{ECZ}$ と $\mathrm{EMM}$ を用いる. 周波数を 025 5 Hz の範囲で変化させたときの実験結果の一例を 図 7 に示寸, 但し, 図7は, f $025 \mathrm{~Hz}$ の時の結果であ る. また, 発泡ゴム内圧力変動に対するアクチュエー 夕の変位量の比 [変位/圧力］に関寸るボード線図を 図 8 に示寸、ここで，圧力波形は，サンプリング時間 (10ms) に対し一定の間隔ごとのデータについて示し ている.また, 変位波形は, SOFMA 単体が拮抗構造 でないことから, SOFMA 内部を加圧し膨張させる場 合と減圧し収縮させる場合で応答が異なる結果となる。 さらに, 図 8 に示寸 Bode 線図は膨張させる側につい て示している.

発泡ゴムの材質が ECZ の場合, ゲインの減衰は EMM よりも大きくなっていることが分かる。また， 低周波域 $(0.1 \mathrm{~Hz}$ 以下)では, ECZ の方が圧力変化に対 する゙変位量は EMM よりも増大する結果となることが 分かる. さらに, 発泡ゴムの密度が大きくなるほどバ ネ力は増大し, 固有振動数が増加することが明らかと なった. また, 位相に関しては $1 \mathrm{~Hz}$ 以下において材質 による差が殆どないことがわかる.

今後, SOFMA のモデル化を行い, 固有振動数の比 較を含めた周波数特性の理論的な解析を行っていく.

\section{6 破裂時挙動}

ゴム系アクチュエータを使用する場合, 内圧レ ベルにより破裂などの問題が生じる危険性がある. 特 に, 人間と接触する機器に応用寸る場合, 破裂に伴う アクチュエータの急激な形状変形が心理的肉体的負担 を使用者に与えると考えられる，そこで，二層型アク チュエータに空気を充填加圧し破裂させた時の応答に ついて検討する. また, 参考までに一層型アクチュエ 一タについても結果を示し特性の比較を行う。

破裂時における挙動を調べるために, レーザ変位 計を用いてアクチュエータが破裂するまで連続的に内 圧を上昇させた時の変位量を測定する.

アクチュエータ内の発泡ゴムの材質が, ECZ (密度 $\left.16 \pm 15 \mathrm{kgm}^{3}\right) ， \mathrm{EMM}\left(\right.$ (密度 $52 \pm 3 \mathrm{kgm}^{3}$ ) の時の破裂 の違いを示す. ここで，二層型アクチュエータの内圧 に対する破裂挙動と伴に, 一層型についての挙動も明 らかにする. まず，一層型における実験結果を図 9 に 示す, また, 図 9 の ECZ, EMM に関して, 破裂まで の圧力と変位の関係を示したものを図 10 に示寸. 図 9(a)において, 密度の低いECZを使用した SOFMA は, 測定開始から約 102 秒後に破裂し, 圧力が急激に減少 している. それに対し, 密度の高い EMM を用いた SOFMA では, 測定開始から約 115 秒で破裂している 
が圧力, 変位とも徐々に減少している。また，図 10 の結果より, 一層型の場合, 初期加圧状態において, 圧力上昇に伴う変位の变化量は僅か比増大寸ることが わかる。最大耐圧力は，ECZ は約 $44 \mathrm{kPa}$, EMM は約 $54 \mathrm{kPa}$ となっている. このことから, 発泡ゴムの密度 が高いほどアクチュエータが破裂しにくくなることが 明らかとなった。破裂のパターンはシリコン肉厚の均 一さ及び発泡ゴム多孔部の変形状態などに影響される ことから，今後詳細に検討寸る必要がある.

次に, 二層型アクチュエータの場合における実験結 果を図 11 及ひ図 12 に示寸。ここで, 図 11 は, 各密 度の発泡ゴムを使用した時の破裂時における圧力と変 位に関寸る応答波形である。また, 図 12 は圧力変動 に対する変位の関係を示している，二層型構造の場合， 発泡ゴム部の加圧により形状変形が生じ, ECZ では約 15.4 秒後に, 密度の高い $\mathrm{EMM}$ は約 122 秒後に破裂が 起こっている. また, EMMの場合, 破裂後の挙動は, 一層型と同様に圧力変動が抑制されていることがわか る. この理由の一つとしては, 発泡ゴム多孔部が破裂 時絞りの役目を果たしていることよるものと考えられ る。また，破裂箇所による影響もあることから，密度 の違いと破裂状態に関する問題について, 今後詳細に 検討しなければならない，次に，圧力変化に対する変 位変化の傾向は，図 12 の結果より，低土域での変位 増大率が一層型と比較して大きいことが分かる.

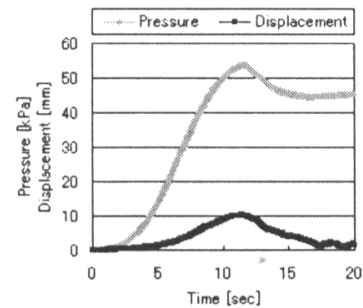

(b) EMM

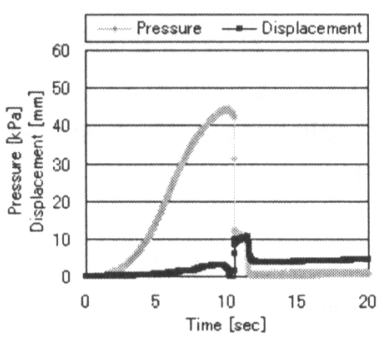

(a) $\mathrm{ECZ}$

Fig.9 Experimental Result of SOFMA(One Layer Type)

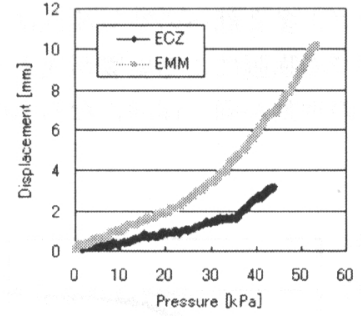

Fig.10 Relation Between Pressure and Displacement

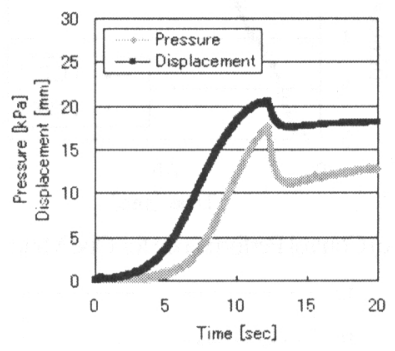

(b) EMM

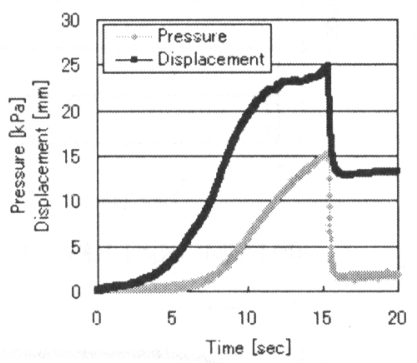

(a) $\mathrm{ECZ}$

Fig.11 Experimental Result of SOFMA (Two layers Type)

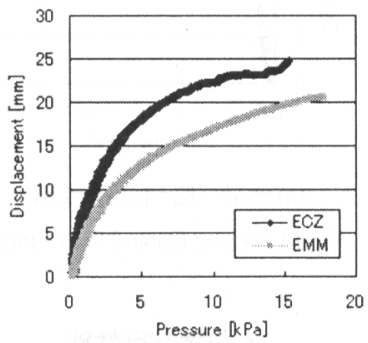

Fig.12 Relation Between Pressure and Displacement

図9及び図11の波形を比較すると破裂時の挙動が大 きく異なっている.この理由の一つとして，SOFMA は発泡ゴムの外側にシリコンがしみ込んでいること から，一層型の場合，シリコンの動きを発泡ゴムが 拘束していることになり, 破裂時の挙動が発泡ゴム の材質により大きく異なる，それに対し，二層型の 
場合は，発泡ゴム多孔部への空気流入による影響よ りも，積層間での膨張による影響が大きくなること から, 破裂時の挙動が同じ傾向になるものと考えら れる。

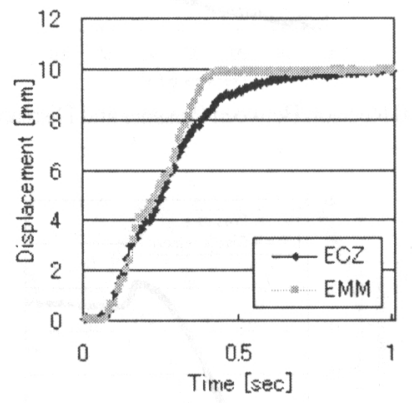

(c) Control Performance for One Minute

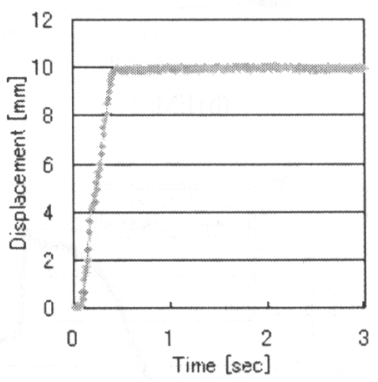

(b) EMM $\left(\mathrm{K}_{\mathrm{P}}=1.1, \mathrm{~K}_{\mathrm{r}}=1.0\right)$

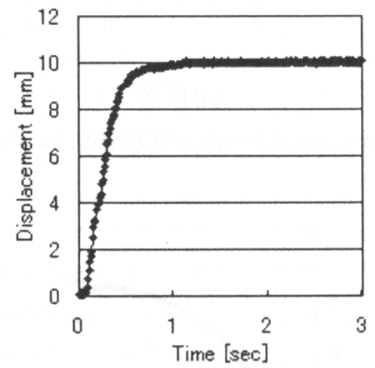

(a) $\mathrm{ECZ} \quad\left(\mathrm{K}_{\mathrm{P}}=1.2, \mathrm{~K}_{\Gamma}=1.0\right)$

Fig.13 Position Control Performance

\section{4. 位置制御性能}

SOFMA を床ずれ防止マットや姿勢調整サポータな どに応用する場合，アクチュエータにより使用者を一 定長さ持ち上げることが必要となる. そこで，本章で は, SOFMA 単体での位置制御性能を明らかにする.

SOFMA の位置制御を行うために, 階層フィードバ ック制御を適用寸る(階層フィードバック制御は,
位置誤差から目標圧力 Pr を設定する(1)式と，圧力制 御式の(2)式により構成される.

$P r=K_{P}(X r-X)+K_{I} \int(X r-X) d t$

ここで, X は現在変位, $\mathrm{Xr}$ は目標変位, $\mathrm{K}_{\mathrm{p}}$ は比例 ゲイン， $\mathrm{K}_{\mathrm{I}}$ は積分ゲインである.

また，比例弁に印加する電圧 V は次式で表される。

$V=V_{0}+K(P r-P)$

ただし， $\mathrm{P}$ は現在圧力， $\mathrm{V}_{0}$ は比例弁の中立点電土, K は比例ゲインである.

目標位置を $10 \mathrm{~mm}$ とした時の実験結果の一例を図 13 に示寸。ここで，(1),(2)式におけるゲインは最適 值に設定している. (a)は，発泡ゴムに ECZ を用い た時の結果であり，(b)は EMM を用いた時の結果で ある. また，(a)と(b)において1秒までの応答波形を 拡大した結果を(c)に示寸。

実験結果より, 密度の低い ECZ を使用した SOFMA の場合, 定常状態に達寸るまでの時間は, 約 0.90 秒で あり, 密度の高い $\mathrm{EMM}$ の時は, 約 0.47 秒となってい ることがわかる. さらに, 定常偏差は, ECZ 及び EMM において約 $0.04 \mathrm{~mm}$ となっている. 以上のこと から, SOFMA に使用寸る発泡ゴムの密度の違いが整 定時間に大きく影響することが分かった.

\section{5. 結言}

本論文では, 高齢者の自立をサポートする機器の 要素として,シリコン外殼型発泡ゴムアクチュエー 夕を提案した. そして，試作したアクチュエータの 基整特性を実験的に明らかにした。 その結果, 発泡 ゴムの材質により特性が異なることを示した. 今後 は，理論的な解析を行う予定である.

謝 辞

本研究の一部は, 科学研究費補助金基盤研究 C(2)(No.14550252)により行われている. また, 実験 機器の一部を提供していただいた SMC 株式会社に 感謝致します。

\section{参考文献}

(1) 吉満, 山本他 : “パワーアシストスーツ用ロー タリアクチュエータの開発” , 計測自動制御学会 システムインテグレーション部門講演会(2002) 
(2)塚越，鎌田，北川：“チューブ形アクチュエー 夕を用いた動作支援に関する提案”，流体計測制御 シンポジウム(2002)

(3)満田, 川村：“可変粘弾性要素を用いた柔軟口 ボットアームの開発” , 計測自動制御学会システム インテグレーション部門講演会(2002)

(4)早川, 森, 津田, 相地, 濱崎他 : “人間親和性 を有するサポータを開発するための生体計測” , シ ステムインテグレーション部門学術講演論文集 (2001)
(5)早川, 森, 津田, 相地, 濱崎他 : “シリコン外 殼型発泡ゴムアクチュエータに関する基礎研究”, 春季フルードパワーシス テム講演会 (2002)

(6)川村，宮田他：“空気圧駆動システムのための 階層フィードバック制御則” , 計測自動制御学会論 文集，26-2,204/210(1990) 